\author{
Ks. Jerzy PAŁUCKI \\ (Lublin, KUL)
}

\title{
SWIECCY ADRESACI LISTÓW PAULINA Z NOLI
}

Paulin z Noli należy do grona tych pisarzy, o których $\mathrm{z}$ całą pewnością można powiedzieć, że nie mieli szczęścia w historii. Potomni obeszli się z Paulinem dość obcesowo, chociaż za życia należał do osobistości najbardziej znaczących w cesarstwie rzymskim na przełomie IV i V wieku. Po ludzku sądząc, można by go nazwać nawet bankrutem życiowym, choć sam uważał się za wybrańca Boga.

Pochodzący z najznamienitszego rodu arystokracji galijskiej, bardzo szybko zrobil zawrotną karierę, nawet jak na czlowieka, który z racji swego pochodzenia był do niej niejako przeznaczony. Jako zaledwie 19-letni młodzieniec został senatorem rzymskim, a wkrótce konsulem rozległej prowincji Kampania ze stolicą w Kapui - na południu Italii. Świetną karierę przerwała mu gwałtowna śmierć cesarza Gracjana, jego przyjaciela i protektora. Wynikłe z tego trudności stały się jedną z przyczyn jego nawrócenia ${ }^{1}$. Tak o tym napisał w liście do swego wypróbowanego przyjaciela Sulpicjusza Sewera:

„Samo moje życie na tym świecie, pełne kłopotów i cierpienia sprawiło, że zrodziła się we mnie nienawiść do tego wszystkiego, co niepokoi moją duszę. $Z$ każdym dniem wzrasta we mnie, $z$ koniecznością nadziei i niepokojem rodzącym się z nachodzących mnie wątpliwości, pobożność i religijność"2.

Po nawróceniu się i radykalnej zmianie życia, zaniechał działalności publicznej i udał się z małżonką Tharasią oraz grupą przyjaciół w niedostępne Pireneje,

${ }^{1}$ Na temat przyczyn nawrócenia oraz jego reperkusji zob. szerzej m.in.: Paolino di Nola. Momenti della sua vita e delle sue opere, red. A. Ruggiero - H. Crouzel - G. Santaniello, Nola 1983; J. Pałucki, Nawrócenia w IV wieku oraz ich reperkusje społeczne, VoxP 17 (1997) t. 32-33, 190-196; G. Santaniello, Il ritorno di Paolino a Nola: cronistoria di un viaggio, „Teologia e Vita” 3 (1995) 37-65; S. Prete, Motivi ascetici e letterari in Paolino di Nola, Napoli-Roma 1987, szczególnie ss. 117-136 (La povertà di Paolino: estetismo letterario o sincerità di convertito).

2 Epistula 5,4, CSEL (ed. 2, Wien 1999) 29,27 lub ed. G. Santaniello: Paolino di Nola, Le lettere. Testo latino con introduzione, traduzione italiana, note e indici, vol. I-II, Napoli-Roma 1992, 224-226, przekład wlasny. 
aby tam pogłębiać swoje życie duchowe. W tym czasie nadal pozostawał w centrum uwagi elit, które nigdy nie wybaczyly mu jego „postępku”. Przyczyn tego odrzucenia go przez świat - zwłaszcza przez arystokrację galijską było wiele. Opisuje to św. Ambroży w liście do biskupa Piacenzy Sabina:

„Gdy to usłyszą dostojnicy, cóż powiedzą? Że czlonek z takiej rodziny, z takiego rodu, o takich zdolnościach, takiej elokwencji, opuścil senat, przerywając dziedzictwo swej szlachetnej rodziny"3.

Także ludzie Kościoła przyjęli to radykalne nawrócenie $\mathrm{z}$ wielką rezerwą. niepokojem i nieufnością, podejrzewając go o sympatie do pryscylianizmu ${ }^{4}$ i pelagianizmu ${ }^{5}$, a rozdanie majątku potraktowano jako burzenie porządku spolecznego. Mimo dość powszechnej niechęci ze strony - delikatnie ujmując letniej chrześcijańsko - arystokracji i obaw Rzymu, wpływ Paulina na życie wielu środowisk był ogromny.

Paulin zdecydował się spędzić resztę życia jako asceta, w założonym przez siebie monasterze w Cimitile, maleńkiej miejscowości koło Noli. Wybór tego miejsca był dokładnie przemyślany: to tam - przy grobie męczennika św. Feliksa - rozpoczęła się droga jego nawrócenia, gdzie wielokrotnie przybywał jako konsul Kampanii. Od czasu jego osiedlenia się w Cimitile tam krzyżowały się szlaki dróg korespondencyjnych osób najbardziej znaczących w Kościele przełomu IV i V wieku' ${ }^{6}$ Z Paulinem korespondowali wybitni teologowie - św. Ambroży, św. Augustyn, św. Hieronim i św. Rufin, a także politycy, wysocy urzędnicy cesarscy, senatorowie i liczni małżonkowie z różnych sfer. Szerokie grono korespondentów świeckich oraz lektura listów Paulina upoważnia do zabrania głosu na sympozjum poświęconym roli świeckich w życiu Kościoła. Zachowane listy są jedynie cząstką jego obszernej korespondencji. Nieraz $z$ treści jednego zachowanego listu można wnioskować, że jest on jedynie ogniwem w całej serii kierowanych do tego samego adresata.

W wydaniu krytycznym - 29 tomie CSEL, znajdujemy 51 listów Paulina skierowanych do 21 adresatów. Wśród nich jest 21 listów skierowanych do 7 adresatów, o których możemy powiedzieć, że byli to ludzie świeccy, przynajmniej na pewnym etapie korespondencji. Kilku z nich porzuciło „sprawy tego

${ }^{3}$ Epistula 27, 3, SAEMO 19, 252, thum. J. Nowak: Św. Ambroży z Mediolanu, Listy, Kraków 1997, BOK 8, 198.

${ }^{4}$ Szerzej na ten temat zob. G. Santaniello: Paolino di Nola, Lettere, I, dz. cyt., Introduzione, s. 53-60 (Paolino priscillianista?).

${ }^{5}$ Por. tamże, s. 70-78 (Paolino e il pelagianesimo); A. Buondonno, L'Antipelagianismo di s. Paolino, Napoli 1944.

${ }^{6}$ Por. A. Esposito, Il messaggio di San Paolino vescovo di Nola - dall'epistolario, NapoliRoma 1986; D.E. Trout, Paulinus of Nola. Life, Letters and Poems, Los Angeles 1999; A. Ruggiero, Agostino, Paolino di Nola e l'epigrafe per Cinegio, „Impegno e Dialogo” 8 (1992) 147-181; Il ritorno di Paolino. 80 dalla traslazione a Nola. Atti, documenti, testimonianze letterarie, red. A. Ruggiero, Napoli - Roma 1990. 
świata" i podążyli bądź wprost do Cimitile, aby zamieszkać w monasterze razem z Paulinem i Tharasią, bądź też pozakładali wlasne wspólnoty. Byli to: małżonkowie Apro i Amanda oraz Eustachiusz z żoną Galią, asceci Santo i Amando, a także Giovo, Makariusz, Pammachiusz oraz Sulpicjusz Sewer, choć znaczna część zachowanej korespondencji z tym ostatnim dotyczy już późniejszego okresu - czasów jego życia we wspólnocie. Trudno nie wspomnieć jeszcze o jednym świeckim adresacie listów Paulina, o istnieniu którego dowiadujemy się z 4 zachowanych listów napisanych do niego przez Auzoniusza. Lektura tych ostatnich pism wyraźnie świadczy, że Paulin, choć zrazu niechętnie, to jednak na te listy odpowiadał. Co więcej, tematyka tej korespondencji jest bardzo konkretna, a forma wielce dramatyczna.

Wymienionych wyżej adresatów podzieliłem na dwie zasadnicze grupy: pierwszą stanowią adresaci, którzy cały czas pozostawali w świecie, drugą ci, którzy na pewnym etapie, pod znacznym wpływem Paulina, podjęli drogę życia ascetycznego.

\section{I. „LUDZIE TEGO ŚWIATA”}

Pierwszą niejako podgrupę stanowią tu ci, z którymi Paulin znał się od najmłodszych lat i z którymi łączyły go bądź więzy krwi, jak np. Giovo - kuzyn Paulina, bądź też więzy pokrewieństwa duchowego jako mistrza i ucznia, jak np. Auzoniusz - nauczyciel Paulina i w znacznej mierze autor jego sukcesów politycznych. Przedmiotem korespondencji z tymi dwoma adresatami były tematy związane $\mathrm{z}$ wiarą. Paulin dążył do ich nawrócenia, ale jego działania nie przyniosły oczekiwanych owoców.

1. Giovo - to jedyny z członków rodziny Paulina, który, jakkolwiek był raczej sceptykiem religijnym (negował m.in. stworzenie świata przez Boga i opiekę Bożej Opatrzności nad nim), nie potępił jego decyzji o porzuceniu świata, rozdania majątku i prowadzenia życia ascetycznego, choć niejednokrotnie sobie $\mathrm{z}$ niego po bratersku dworował. Zachował się tylko jeden list Paulina do Giovo. Jego lektura świadczy jednak o tym, że było ich wiele. Jest to list 16 w kolekcji. Dołączona jest do niego pieśń - Carmen 22, w której Paulin ukazuje wielkość Bożej Opatrzności ${ }^{7}$. W pierwszej części tego listu Paulin dyskutuje

${ }^{7}$ Na temat teologii w piesniach Paulina zob. m.in.: A. Ruggiero, Teologia e dossologia nei Carmini di Paolino, w: Mia sola arte e la fede, red. L. Longobardo - D. Sorrentino, Napoli 2000, 7998, który stwierdza (s. 83), że chociaż „Pieśni”, ze względu na swoisty rodzaj nie mogą dać całościowej, syntetycznej wizji teologicznej, to jednak w przypadku Paulina można mówić o swoistej metodzie i kluczu, w jakim należy czytać jego teksty poetyckie, które co prawda w pierwszym rzędzie ukazują jego przeżycia mistyczne, gdzie uprzywilejowane są wprawdzie obrazy i fantazja literacka, to jednak można w nich z powodzeniem śledzić także linię tematów dogmatycznych, 
z mało ortodoksyjnymi poglądami kuzyna, w drugiej zaś zachęca go i wręcz wzywa do nawrócenia, poświęcenia Chrystusowi swego życia, a także talentów; Giovo był bowiem poetą i wielkim znawcą literatury. Zaleca mu, aby te talenty i caly swój majątek oddał do dyspozycji Kościoła.

Nie mamy żadnych śladów, które by wskazywały, że Giovo pozytywnie zareagował na zachętę swego kuzyna ascety. Wiele jednak wskazuje na to, że ze strony Giovo, jedynie na pozór - jak się wydaje - wesołego lekkoducha, jego postawa niedowiarka mogła być swoistym droczeniem się, bo dawał Paulinowi wielkie sumy na budowę świątyń. Jedna $\mathrm{z}$ takich darowizn stała się tematem dyskusji. Otóż statek przewożący wielką sumę pieniędzy przeznaczonych na budowę bazyliki w Cimitile i Fondi, rozbił się w czasie burzy morskiej. Jego wrak dryfował ku lądowi i osiadł na mieliźnie, dzięki czemu cała suma ocalała, nikt jej nie rozgrabił, mimo że cała załoga zginęła. Zdaniem Paulina stało się tak na skutek cudownej interwencji Boga, gdyż były to pieniądze przeznaczone na świątynię. Giovo wyjaśnia pobożnemu kuzynowi, że stało się tak nie dzięki jakiemuś nadzwyczajnemu działaniu Boga, ale dlatego, że statek wylądował na wybrzeżu, które było własnością jego rodu, do którego zresztą obaj należeli. Ponadto znalazcy wraku ze skarbem znali Paulina i powszechnie szanowali, więc nikt nie ośmieliłby się tknąć skarbu doń należącego.

2. Następny koresponclent to Auzoniusz ${ }^{8}$ - w tym wypadku, jak już wspomniano, zachowały się jedynie jego listy do Paulina; warto jednak wspomnieć o nim ze względu na jego postawę, tak charakterystyczną dla większości chrześcijańskich arystokratów Galii, których nawrócenie było na ogół jedynie koniunkturalne ${ }^{9}$. Z wypowiedzi Auzoniusza wynika, że nie dziwi się, iż jego uczeń przyjął chrzest, ale na tym powinien poprzestać. Mistrz potępia zdecydowanie rygoryzm ascetyczny swego ucznia i wzywa go do opamiętania się. I w tym przypadku Paulin nie wiele zdzialał: Auzoniusz został nadal - w pewnym sensie - pogańskim poetą, zastępując w swych utworach, po przyjęciu chrztu, imię Zeusa - imieniem Chrystusa. Oczywiście takie ujęcie jest wielkim uproszczeniem całego problemu. Chrystianizacja elit rzymskich nie jest przedmiotem niniejszej publikacji, ale wydaje się jednak słusznym wskazać na ówczesny problem chrześcijańskiej formacji młodzieży ${ }^{10}$.

chociaż czytelnik zmuszony jest niejako do współpracy z autorem; por. także A. Salvatore, L'aspetto biblico-religioso nel programma di Paolino di Nola, Estratto dall'Annuario 1960-1969 del L.P. Giannone di Caserta 4, Messina - Firenze 1967, szczególnie s. 477; G.D. Errico, Dottrina e poesia nelle Lettere di Paolino di Nola. Note critiche, „Impegno e Dialogo" 9 (1991) 133-140.

${ }^{8}$ Por. A. Swoboda, Pojęcie przyjaźni w listach Paulina z Noli i Auzoniusza. Studium porów. nawcze, Poznań 1995; G. Guttiella, Ausonio e Paolino; raporti letterari e umani, „Impegno e Dialogo" 10 (1995) 177-189.

9 Por. P. Brown, Religione e società nell' età di Sant'Agostino, Torino 1975, 151-171.

${ }^{10}$ Szerzej na temat postawy Auzoniusza, całej jego złożoności zob. V. Messana, Aspetti $e$ 
3. Nieco inaczej przedstawia się sprawa $z$ następnym adresatem Makariuszem, z którym Paulin korespondował pośrednicząc w sprawach typowo przyziemnych. Jest to list $49 \mathrm{w}$ kolekcji. Zasadniczo, mimo licznych rozbieżności, przyjmuje się, że Makariusz był przyjacielem męża Melanii Młodszej, być może - zdaniem Palladiusza - ekswikariuszem Prefektury Rzymskiej. Byłby to zatem wysoki i wpływowy urzędnik cesarski. Paulin $z$ pewnością znał go dobrze jeszcze z czasów, gdy był senatorem rzymskim, a następnie konsulem Kampanii. W czasie, gdy pisał do Makariusza, ten przebywał w swej rezydencji na Sycylii. Powód napisania listu był bardzo prozaiczny i należy do wyjątku w korespondencji Paulina. Nasz autor prosi w nim Makariusza, aby ten interweniował $\mathrm{u}$ innego urzędnika - Postumiana, by ten $\mathrm{z}$ kolei doprowadzil do oddania barki pełnej zboża jej prawowitemu właścicielowi, którego imienia nie podaje. Zboże to jakąś drogą niezgodnych z prawem kombinacji - może w ramach ściąganego podatku - zabrał jeden z zarządców Postumiana. Wiemy, że barka ta uszkodzona w czasie burzy wylądowała na wybrzeżu koło Luki. Należało więc zadbać o naprawienie szkód. Paulin zainteresował się losami barki dlatego, iż jedyny majtek, który przeżył katastrofę, opowiadał mu o uzyskaniu cudownej pomocy Chrystusa i św. Feliksa w czasie burzy.

\section{ADRESACI, KTÓRZY PORZUCILI ŚWIAT UDAJĄC SIĘ NA PUSTYNIĘ}

1. Pammachiusz - to jeden $z$ najbardziej wpływowych arystokratów rzymskich, senator. Paulin znał go jeszcze z czasów swego rezydowania w Rzymie i z posiedzeń senatu: był on już wtedy gorliwym chrześcijaninem, a Paulin zaledwie letnim katechumenem. Prawdziwa przyjaźń między nimi zrodziła się dopiero wówczas, gdy Paulin osiadl jako asceta w Cimitile. Zachowane pismo pochodzi z czasów, gdy Paulin był już biskupem Noli, i jest listem konsolacyjnym $^{11}$ skierowanym do Pammachiusza po śmierci żony. Pammachiusz porzucił wtedy dotychczasowy sposób życia, majątek przeznaczył na pomoc dla ubogich, a sam $w$ stroju ascety (włosiennica $z$ sierści wielbłąda), wśród szyderstw $z$ tego powodu ze strony kolegów senatorów, gorliwie uczestniczył w posiedzeniach Senatu.

2. Kryspinian - zachowały się do niego dwa listy 25 i 25 bis. Był prostym żołnierzem, o którym wielokrotnie opowiadał Paulinowi jego osobisty kurier -

\footnotetext{
momenti di formazione scolare (e religiosa) nel «Corpus» di Ausonio, w: Crescità dell'uomo nella catechesi dei Padri (età postnicena), red. S. Felici, Roma 1988, 201-223.

" Por. A. Quacquarelli, Una consolatio cristiana - Paolino di Nola, w: Atti del convegno: XXXI cinquantenario della morte di s. Paolino di Nola (431-1981), Roma 1982, 121-142.
} 
Wiktor, a uprzednio także żołnierz i przyjaciel Kryspiniana. W pierwszym liście Paulin zachęcał go do porzucenia dotychczasowego sposobu życia i przyłączenia się do wspólnoty monastycznej. Gdy list ten nie przyniósł pożądanego efektu, napisał do niego drugi list, utrzymany już w konwencji bardziej stanowczej zachęty. Paulin odwołal się w nim do argumentów trudnych do odrzucenia, m.in. przypominal Kryspinianowi jego wiek, delikatnie mówiąc już dojrzały i wynikającą $z$ tego potrzebę spieszenia się. To poskutkowało - Kryspinian porzucił wojskową służbę i osiadł we wspólnocie ascetów.

3. Santo i Amando - to adresaci 2 kolejnych listów. Santo był przyjacielem Paulina od lat młodości, Amando zaś młodzieńcem, który za przykładem Paulina podjąl decyzję o porzuceniu świata i rozpoczęciu życia ascetycznego, jakkolwiek należał już prawdopodobnie do niższego kleru. Obaj napisali list do Paulina informując go o podjęciu decyzji pogłębienia życia duchowego i udaniu się na pustelnię. Z pierwszego listu Paulina (Ep. 40) dowiadujemy się o częstej wymianie korespondencji pomiędzy nim i Santo. Nolańczyk pochwala ich decyzję i podaje im wskazówki, o które go prosili. Dowiadujemy się także, że sam przechodził w tym czasie jakieś wielkie duchowe rozterki. List 41 jest jakby uzupełnieniem i kontynuacją poprzedniego, nie został nawet zaopatrzony w odpowiedni adres ani nawet stosowne pozdrowienia. Paulin dziękuje za przesłany mu psałterz oraz spis tytułów jego listów skierowanych do adresatów z Galii, z czego wynika, że był to początek kompletowania pierwszego zbioru listów Biskupa $z$ Noli. Nasz autor dziękuje swym adresatom za tę listę i przyznaje, że już nie pamiętał, że takowe listy napisał. Jak wiadomo listy stanowiły bardzo istotny element $w$ działalności pasterskiej Paulina ${ }^{12}$. Prawdopodobnie na prośbę adresatów, przekazaną przez posłańca, Paulin komentuje w tym liście fragment ewangelii o 10 pannach. Wyjaśnia, m.in., że panny nieroztropne są symbolem ludzi pozbawionych cnót chrześcijańskich, natomiast mądre symbolizują tych, którzy są bogaci w dobre dzieła.

4. Małżonkowie Apro i Amanda. Apro był znanym adwokatem i urzędnikiem akwitańskim. On to z żoną Amandą wielokrotnie zwracali się do Paulina $\mathrm{z}$ prośbą o różne rady. $\mathrm{Z}$ tej korespondencji zachowały się 3 listy ${ }^{13}$. W pierwszym z nich (Ep. 38) Paulin odpowiada małżonkom na wcześniejszy i zachęca ich do utrzymania decyzji o podjęciu drogi życia ascetycznego. Prosi też, aby Apro nie zwracał uwagi na nieżyczliwe komentarze środowiska, w którym oboje żyją, by nie ulegali namowom ze strony ludzi świata, przeciwników

${ }^{12}$ Por. S. Costanza, Catechesi e poesia nei Carmi XXII, XXV e XXXI di Paolino di Nola, w: Crescità dell'uomo nella catechesi dei Padri (età postnicena), red. S. Felici, Roma 1988, 225-284; R. Maradino, I dolci colloqui di Paolino nell'Epistolario, „Impegno e Dialogo" 9 (1993) 141-169.

${ }^{13}$ Por. Epistolae 38, 39, 44, CSEL 29, 323-339, 369-378. 
takiej decyzji. Następne dwa listy są podpisane także w imieniu Tharasii. Apro, podobnie jak Paulin, nawrócił się na chrześcijaństwo pod wpływem swej małzonki. Ostatecznie porzucił świat i karierę, przyjął kapłaństwo i - podobnie jak Paulin z Tharasią - zamieszkali na wsi. Apro zajął się duszpasterstwem, Amanda zaś zamieszkała w sąsiedztwie we wspólnocie żeńskiej.

5. Malżonkowie Eucheriusz i Gala. Do nich skierowany jest list 51, w którym Paulin podkreśla szczególnie rolę przyjaźni, bazującej na miłości do Chrystusa ${ }^{14}$. Pod wpływem Paulina i za jego przykładem Eucheriusz i Gala porzucili życie światowe i udali się na wyspę nazywaną dziś wyspą św. Małgorzaty. Zamieszkali tam ze swoimi dziećmi. Na innej pobliskiej małej wyspie mieszkał już z grupą swych uczniów, w założonym przez siebie klasztorze, znany wcześniej Paulinowi Honorat $z$ rodu Konsulów. Między mieszkańcami tych dwóch wysp nawiązała się ścisła wspólpraca, polegająca głównie na korespondencyjnej wymianie myśli i doświadczeń.

6. Ostatni z omawianych adresatów, do którego skierowany jest pierwszy list $\mathrm{z}$ tej kolekcji, to Sulpicjusz Sewer. Korespondencja pomiędzy Paulinem i Sulpicjuszem jest najobfitsza. Zasadniczo dotyczy ona jednak już czasów, gdy Sulpicjusz prowadził życie mnicha kapłana. Zachował się jednak jeden list $\mathrm{z}$ czasów, gdy był on jeszcze osobą świecką. Sulpicjusz po śmierci zony, zachęcony przez teściową - Bassulę (rzadki to przypadek - słuchania teściowej wbrew woli ojca) sprzedaje i rozdaje majątek, po czym zakłada wspólnotę. Paulin napisal ten list do Sulpicjusza, gdy ten rozważał podjęcie podobnej decyzji, jak Nolańczyk ${ }^{15}$. List ten pisany był $z$ Barcelony, to znaczy już po tzw. drugim nawróceniu Paulina i przyjęciu przez niego święceń kapłańskich, gdy ten już rozdał majątek i podjął decyzję o zamieszkaniu na stałe w Noli Cimitile. On sam doświadczył również wielu upokorzeń ze strony najbliższych w związku z tak radykalną zmianą życia, zatem doskonale rozumiał rozterki Sulpicjusza, który właśnie teraz przechodził podobne doświadczenia.

Listy Paulina, poza nielicznymi wyjątkami, dotyczą spraw duchowych. Są to często komentarze fragmentów biblijnych, pisane na życzenie adresatów. Za-

\footnotetext{
${ }^{14}$ Na temat przyjaźni i jej znaczenia w życiu duchowym chrześcijanina powstało sporo publikacji, m.in. w języku polskim, np. A. Swoboda, Pojęcie przyjaźni w listach św. Paulina z Noli iśw. Sydoniusza Apolinarego, Poznań 1995; R. Maradino, I dolci colloqui, dz. cyt, szczególnie ss. 166169 (Conclusione: amicizia spirituale e amore di unità nella teologia dell'agape).

${ }_{15}$ Por. G. Santaniello, Il cammino ascetico nel dialogo epistolare di Paolino, szczególnie s. 129 150 (La conversione e la visione del mondo nella corrispondenza con Sulpicio Severo), w: Mia sola arte, dz. cyt.
} 
wierają też wskazówki i rady dotyczące życia duchowego; wielu adresatów Paulin wpierał w podejmowaniu trudnych decyzji, bądź zachęcał do wytrwania w już podjętych ${ }^{16}$.

Korespondencja Paulina jest doskonatym źródłem dla tych, którzy pragną śledzić początki życia monastycznego, reakcje chrześcijan i pogan na ten wciąż nowy fenomen na Zachodzie, a także próby ukazania udziału ludzi świeckich w życiu Kościoła i Państwa ${ }^{17}$. Postawy ludzi świeckich - o bardzo zróżnicowanym poziomie wiary, statusie społecznym i zaangażowaniu w życie Kościoła od sceptycznego Giovo do heroicznie świątobliwego senatora uczęszczającego na obrady senatu we włosiennicy, od ubogiego żołnierza do wpływowego urzędnika cesarskiego.

\section{DIE LAIEN IN DEN BRIEFEN DES HL. PAULINUS VON NOLA}

\section{(Zusammenfassung)}

Die Briefe des hl. Paulinus von Nola betreffen überwiegend mit dem Geistesleben. Meistens gab es biblische Kommentare, die er, erfüllend Wünsche seiner Empfänger, schrieb. Sie enthalten auch verschiedene geistliche Hinweise. Auf diese Weise ging Paulinus seinen Adressaten mit Rat an die Hand. Paulinus' Korrespondenz ist überdies die vollkommene Quelle für diese, die sich mit den Anfängen des monastischen Lebens und Reaktionen der Christen und der Heiden danach beschäftigen. Sie zeigt auch die Teilnahme der Laien über sehr unterschiedlicher Niveau der Glaube im Leben der Kirche und des Staates. Die Haltungen der Menschen sind sehr mannigfaltig: von skeptischen Giovo in den gottgefälligen Senator, von dem armen Soldaten in den einflussreichen kaiserlichen Beamten.

${ }^{16}$ Por. Funzione e scelta di un genere letterario, w: Mia sola arte, dz. cyt., s. 99-104.

17 Por. E. dal Covolo, Chiesa società politica. Aree di „laicita" nel cristianesimo delle origini, Roma 1994; G. Dorival, La patristique comme mouvement de recuperation de l'hellenisme et de la culture antique au profit de la foi chretienne, w: Anthropos Laikos, red. M. Vannier - O. Wermelinger - G. Wurst, Fribourg 2000, 91-102. 